\title{
Flexible work and immigration in Europe
}

\author{
Article
}

Accepted Version

Raess, D. and Burgoon, B. (2015) Flexible work and immigration in Europe. British Journal of Industrial Relations, 53 (1). pp. 94-111. ISSN 0007-1080 doi:

https://doi.org/10.1111/bjir.12022 Available at https://centaur.reading.ac.uk/60358/

It is advisable to refer to the publisher's version if you intend to cite from the work. See Guidance on citing.

Published version at: http://onlinelibrary.wiley.com/doi/10.1111/bjir.12022/abstract

To link to this article DOI: http://dx.doi.org/10.1111/bjir.12022

Publisher: Wiley

All outputs in CentAUR are protected by Intellectual Property Rights law, including copyright law. Copyright and IPR is retained by the creators or other copyright holders. Terms and conditions for use of this material are defined in the End User Agreement.

\section{www.reading.ac.uk/centaur}

\section{CentAUR}

Central Archive at the University of Reading

Reading's research outputs online 
Flexible Work and Immigration in Europe

\author{
Damian Raess \\ (corresponding author) \\ Département de science politique \\ et relations internationales \\ Université de Genève \\ 40, Boulevard du Pont d'Arve \\ 1211 Genève 4 \\ Switzerland \\ Tel: +41 223798385 \\ Damian.Raess@unige.ch
}

\author{
Brian Burgoon \\ Department of Political Science \\ University of Amsterdam \\ The Netherlands \\ B.M.Burgoon@uva.nl
}

Word count (all-in): 7’250

\begin{abstract}
Immigration has risen substantially in many European economies, with far-reaching if still uncertain implications for labor markets and industrial relations. This paper investigates such implications, focusing on employment flexibility, involving both 'external flexibility' (fixedterm or temporary agency and/or involuntary part-time work) and 'internal flexibility' (overtime and/or balancing-time accounts). The paper identifies reasons why immigration should generally increase the incidence of such flexibility, and why external should rise more than internal flexibility. The paper supports these claims using a dataset of establishments in sixteen European countries.
\end{abstract}

Acknowledgements:

Earlier drafts of this paper were presented at the Staff Seminar, Centre for Sociological Research, Katholieke Universiteit Leuven, October 20, 2010 and at the 3-Länder-Tagung Conference of the Austrian, German and Swiss Political Science Associations, University of Basel, January 13-14, 2011. We thank participants, in particular Beatrice Eugster and Valeria Pulignano, as well as two anonymous reviewers and the Editor for helpful comments and suggestions.

\title{
Funding:
}

Financial support for this research was provided by the Universities of Amsterdam and Geneva, and by the project 'Politics, Economics and Global Governance: The European Dimensions' (PEGGED) funded by the European Commission's $7^{\text {th }}$ Framework Programme for Research (Grant Agreement no. 217559). 
International migration has become among the most controversial and important developments in contemporary European political economy and industrial relations. This reflects in part the highly visible rise in foreign-born shares in many European economies since the 1970s, parallel to turbulent labor market developments. But it also reflects the widely debated consequences of immigration for virtually all aspects of industrial relations, including labor supply, wages, and employment.

Despite such controversy, we know little about immigration's implications for one of the most important developments in contemporary industrial relations: the rise and spread of flexible work. Such practices involve non-standard work, especially part-time and temporary work contracts, and flexible working time by full-time workers, especially overtime and varying work weeks via 'balancing-time' accounts (e.g., European Commission 2006; Hunter et al. 1993). Such flexibility is a source of both wonder and worry. Some expect it to help combine work with family or to increase productivity (Booth and van Ours 2008; Cappelli 1999; De Graaf-Zijl 2005; Doogan 2005; Guest 2004; Knell 2000). But others find that flexibility engenders social fragmentation and isolation, or job and income insecurity (Beck 2000; De Witte and Näswall 2003; Erlinghagen 2008; Green et al. 2010; Heery and Salmon 2000). Whether one welcomes or laments flexible employment, its rise deserves explanation. How and whether flexible working practices have anything to do with immigration, as opposed to domestic political and economic conditions, is an open question. The dominant view is that flexible contracts and working time are shaped by domestic factors - where immigration or other globalization features are either ignored or don't matter (Golden and Appelbaum 2006; Gustafsson et al. 2003; Hunter et al. 1993; Kalleberg 2001; Smith and Neuwirth 2008). Those studies exploring global economic forces offer competing and limited views into migration's role in shaping flexible employment. Some find that trade and capital openness create pressures which increase flexibility, at least for particular socioeconomic 
groups surveyed (e.g., Blair-Loy and Jacobs 2003; Jirjahn 2008; Lillie 2012; McDowell et al. 2008; Raess and Burgoon 2006). A few draw the opposite conclusion, where globalization increases profitability, which gets passed-on to workers as less rather than more flexible work (e.g., Flanagan 2006). Still others have found globalization to spur flexible employment particularly where works councils negotiate trade-offs between employment and working conditions (Burgoon and Raess 2009). Existing studies, however, have limited empirical reach, focusing on facets of globalization other than immigration and with no large-N work considering flexibility-effects of immigration.

To redress such shortcomings, this study explores arguments about how immigration affects two kinds of employment flexibility: fixed-term or temporary agency work and employer-mandated part-time work, which we term 'external flexibility'; and overtime and balancing-time accounts, which we term 'internal flexibility'. As Section One explains, migration creates opportunities for labor substitution that should increase employment flexibility generally. But by directly increasing available and more docile labor supply, immigration should more positively affect non-standard contracts constituting external flexibility than it does working-time practices constituting internal flexibility.

Sections Two and Three test these arguments on a survey of private establishments in sixteen European countries that allows judging how immigration affects flexibility standards at the level where standards are most directly decided. The analysis reveals patterns broadly in line with expectations. On the one hand, foreign-born shares tend to be unrelated to the incidence of internal flexibility, as measured in incidence of paid overtime, of balancing-time accounts, or a composite of both. On the other hand, foreign-born shares tend to strongly spur external flexibility: fixed-term or agency employees, employer-mandated part-time employees, or a composite of both. Furthermore, the latter pattern predominates the way immigration 
influences a combined measure of both internal and external flexibility: foreign-born shares modestly increase the incidence of composite measures of internal and external flexibility.

The results suggest that immigration shapes flexibility practices in European labor markets, but in ways that vary across different aspects of flexibility. They clarify the origins of a key development in working life. And they help clarify consequences of immigration for meso-level political-economic life, thereby further bridging scholarly study of international political economy and of industrial relations (Haworth and Hughes 2003).

\section{Flexibility and immigration}

Our expectations about immigration's implications distinguish different kinds of flexibility and underlying political interaction of employers and workers. Employment flexibility includes both contract and work-time flexibility. Research on (organizational) flexibility suggests two strategies of flexible labor utilization: external (or numerical) vs. internal (functional) flexibility (Atkinson 1984; Cappelli and Neumark 2004). Employers’ need for flexibility can be achieved by rendering firms externally flexible, with work organized so that adjustment to demand occurs via nonstandard work and/or via high labor turnover. Nonstandard employment involves deviation from full-time employment, and includes fixed-term contracts (i.e, short-term contracts for finite periods on an as-needed basis), temporary agency contracts (i.e., employment via a temporary agency company), and part-time work (Kalleberg 2001: 483). ${ }^{1}$ In internally flexible firms, core workers experience flexible working-time, such as night-shift or overtime work, or balancing-time accounts where above-standard hours are accumulated without extra pay in a working-time account and compensated later by reduced hours. Such time-related conditions are often introduced alongside other arrangements like variable pay and job rotation (McDuffie 1995). The key difference between the two kinds of employment flexibility is that adjustment costs fall on 
peripheral workers with external flexibility and on core workers with internal flexibility. External flexibility, thus, entails labor market dualism, insider-outsider segmentation.

Setting either kind of employment flexibility reflects employer and employee preferences. Employers tend to want the option of flexible hours and non-standard contracts to allocate personnel efficiently across business cycles (Bosch and Lehndorff 2001; Hinrichs et al. 1991). This may be particularly important with just-in-time production, close client orientation and longer machine running-time of capital-intensive assembly lines - all of which chafe against regular, full-time contracts with clearly defined hours-limits in a given week. In Europe since the late 1970s, employers have negotiated reductions in standard hours of fulltime employees in exchange for flexibility in daily, weekly, and weekend work (Bosch 1990; Plantenga and Dur 1998).

Among employees, preferences can be expected to vary substantially across sectors, occupations and personalities of workers (Tijdens 2003; Väisänen and Nätti 2002). Some workers clearly can see benefits to both internal and external flexibility (Kalleberg 2000; Krausz 2000). But internal flexibility is likely less of a threat to the employment condition of core workers than external flexibility. Balancing accounts might enhance workers' sovereignty over their time allocation. And some workers might welcome extra compensation associated with overtime. Employees with flexible contracts, in contrast, face greater wage and unemployment risks than their counterparts on standard contracts (Gash and McGinnity 2007). Survey evidence suggests that employees tend to prefer more regular and fixed working hours and, certainly, employment contracts - being predictable and easier to combine with family and other social responsibilities (Beard and Edwards 1995; De Wolff 2000).

Against the background of employer and employee attitudes, immigration can be expected to have offsetting and skill-specific effects for flexibility in advanced economies. On the one hand, migration might spark forces yielding more flexibility for particular workers, as 
part of the easier 'sweating' of those workers competing in similar skill categories as migrant workers (Borjas et al. 1996; Feenstra and Hanson 1996). On the other hand, immigration might translate into more limited flexibility: migration can alter wage bargains and lower costs without introduction of flexibility, and these changes can improve profitability for enterprises that get passed onto core workers as more regular employment and fewer irregular and overtime hours (Flanagan 2006). This might hold in particular where migration complements more than substitutes for native worker profiles (Hanson et al. 2001). Alternatively, the employment or poverty risks generated by immigration might lead workers to demand reduced flexibility as internal compensation for such risks (Katzenstein 1985).

However, several features of Europe's immigration have implications for workplace bargaining that should yield more flexibility. With the physical presence of migrants in the economy, employers have an attractive option of substituting foreign for native workers instead of shifting jobs abroad, because it provides them less uncertainty and a faster response to changing international price pressures. This general consideration could strengthen employer pressure to increase internal as well as external flexibility.

Foreign-born workers tend to have skill profiles and socioeconomic backgrounds providing employers greater latitude to pressure immigrants than applies to native workers. The kind of migration applying to European countries tends to be of a more skewed, lower skill profile than native workers for whom they are substitutes. This is captured by how native populations in Europe have higher education on average (lower share of primary and higher share of secondary and tertiary education) than their foreign-born populations - more than is the case in non-European OECD countries (OECD 2008: Table 3.1). This skew is different than that applying to the trade pattern of European economies, where intra-industry trade is as or more extensive than inter-industry trade. Such skew shows up in how immigration in many settings, more than trade, yields up-skilling and dampens less-skilled wages (Borjas et al. 
1992, 1996; Okkerse 2008). Foreign-born employees also often have social and legal positions that render them vulnerable in relation to employers. Europe's foreign-born workers experience higher unemployment, are less familiar with regulations and rights, have precarious legal positions and often come from settings with exploitative working conditions that may make them more docile in confronting employers (Camarota 1998; Newman and Lennon 1995; Woolfson 2007).

In short, immigration can be expected to increase the tendency of foreign-born workers to accept more flexible working conditions than do their native counterparts, constituting a composition effect. And it can be expected to embolden and empower employers to negotiate flexible working-time arrangements and contracts in workplace bargaining. Such responses from employers are, to be sure, mediated by stereotypes across particular immigrant groups (MacKenzie and Ford 2009; McGovern 2007; Waldinger and Lichter 2003). ${ }^{2}$ But the general expectation these various considerations underscore is simple: Hypothesis One: Immigration should positively affect the incidence of internal and external flexibility.

Our second expectation is that such effects are likely stronger and more positive with respect to external than with internal flexibility. Incumbent workers likely defend against the hollowing-out of standard employment in the face of a larger, more docile labor pool. As discussed above, core workers prefer overtime or modest hours variation over nonstandard contracts. But they may accept non-standard contracts (for primarily foreign-born workers) to protect their own employment, including less internal flexibility—forming cross-class coalitions with employers to defend insiders (Olsen 2005). With cheap and malleable immigrant pools, in short, employers may use migrant workers as external buffers to adjust to global markets. Indeed, some research has found that migrant workers tend to participate in the secondary labor market (King and Rueda 2008; McDowell et al. 2008; Piore 1979). 
A further reason to expect immigration to play out more strongly for external than internal flexibility is that employers, especially in the more regulated EU countries, may follow a deliberate deregulatory agenda that uses migrant workers to liberalize EU labor markets (Lillie and Greer 2007). Because liberalization of atypical employment is arguably a stronger threat to regulated labor markets than is flexible work-time arrangements, and because of greater malleability than their native counterparts, migrant workers might be more easily driven into nonstandard employment contracts and likely to increase the tendency of employers to consider such contracts. These considerations motivate our second hypothesis: Hypothesis Two: Immigration should more strongly positively affect external flexibility (fixed-term or agency work and involuntary part-time work) than it does internal flexibility (overtime and balancing-time accounts).

These hypotheses do not preclude other, more nuanced possibilities. Atkinson (1984) suggests that internal and external flexibility might be imperfect substitutes (c.f., Lillie 2012). If so, immigration's hypothesized effects for external flexibility ought to be dampened by existing internal flexibility, and vice versa. We explore this possibility below. However simple our main expectations, evidence for them is hard to find, given the lack of data capturing variation in immigration exposure that matches data on employment flexibility where such flexibility is most directly set - the individual establishment.

\section{Evidence from Establishment Surveys in Europe}

We test the above expectations by analyzing establishment-level data in European countries using the Establishment Survey on Working Time and Work-Life Balance (ESWT) (European Foundation and TNS Infratest Sozialforschung 2007). The ESWT survey was carried out in 2004-2005 in fifteen 'old' and six 'new' member states for a total of $21 \mathrm{EU}$ countries, though matching to the OECD immigration measure narrows the sample to 16 countries (Belgium, Denmark, Greece, Spain, Ireland, Italy, Luxembourg, Netherlands, 
Austria, Portugal, Finland, Sweden, United Kingdom, Czech Republic, Hungary and Poland). Our data comprise a representative sample of private establishments with 10 or more employees from all sectors, excluding agriculture (NACE A), fishing (NACE B), private households (NACE P) and extra-territorial organizations (NACE Q). ${ }^{3}$ Interviews were conducted with human-resource managers or employee representatives in some 9,600 establishments, ranging from some 350 (e.g., Luxembourg) to 1,100 cases (e.g., United Kingdom). The data allows only a focus on variation across establishments at one time point. Despite this limitation, the ESWT dataset provides substantial leverage to test immigration's effects on flexible work, because it focuses on the level at which flexibility is most directly set - the establishment rather than the sector or country - and because it covers countries with widely varying economic and political institutions, ideas and interests.

Dependent variables: External and internal flexibility. The ESWT survey covers a range of items relevant to flexibility of working time and contracts. Our measure of external flexibility focuses on contract flexibility. We consider the incidence of two forms of nonstandard work contracts: fixed-term or temporary agency contracts, and employer-mandated, or 'involuntary', part-time contracts. Fixed-term or temporary agency contracts is a binary measure of whether an establishment has fixed-term or temporary agency contracts (1=establishments with either fixed-term or temporary employees, or employees from a temporary work agency; $0=$ establishments without such employees). ${ }^{4}$ Involuntary part-time contracts is a binary measure of whether an establishment has part-time employees (based on national definitions of part-time) to meet the needs of the employer - as opposed to other reasons, such as employee preference. ${ }^{5}$ Such involuntary part-timers are non-standard workers but likely also more peripheral workers, distinct from part-time employees who prefer parttime work to belonging to the core work-force (see Kalleberg 2001: 483). We also add these two measures to form a composite of external flexibility, as follows: $0=$ neither fixed-term or 
agency contracts nor involuntary contracts; $1=$ either fixed-term or agency contracts or involuntary part-time contracts; $2=$ presence of both fixed-term or temporary agency contracts and involuntary part-time work contracts. In the ESWT sample, fixed-term or agency work and involuntary part-time contracts are weakly correlated (coefficient of correlation=.07, pval.=.008). The average score for fixed-term or agency work is .7 - quite dispersed (std. dev., .46) with Greek enterprises having the lowest incidence (.41) and Czech enterprises the highest (.93). The mean for incidence of involuntary part-time is .12, more dispersed (std. dev., .32) and with the lowest average for Portugal (.02) and Poland the highest (.32).

With respect to internal flexibility, we focus on working-time flexibility that allows varying labor volume through internal means. We consider two such measures: the incidence of a balancing-time account which allows employees to work longer in a given day or week and to compensate this later by working less on other days or weeks; and the incidence of paid overtime work. We measure these as binary variables, as follows: 1=presence of balancing-time accounts (paid overtime); $0=$ no balancing-time accounts (no paid overtime). As with external flexibility, we also report a composite measure of internal flexibility created from the two binary working-time flexibility measures, as follows: $0=$ neither balancing-time accounts nor paid overtime; $1=$ presence of either; $2=$ presence of both. In our ESWT sample, balancing-time accounts and paid overtime correlate negatively (correlation -.14), likely because balancing-time accounts allow employees to accumulate extra hours and be compensated later by time off rather than paid overtime compensation. And the sample's means, hence average incidence, for balancing time and for paid overtime are .31 and .31 , respectively (standard deviation, .46 and .46 , respectively), with Greek enterprises having the lowest proportion of enterprises with balancing-time accounts (.15) and Finnish the highest (.58), and with Belgian enterprises the lowest incidence of paid overtime (.09) and Italy the highest (.59). ${ }^{6}$ 
As a final measure of flexibility, we also report two composites of the incidence of combined flexibility. Combined flexibility categorical is a simple additive composite of the two components of external flexibility and of internal flexibility and hence ranges from 0 to 4. Combined flexibility binary measures the presence of any one of the four components (1=either balancing-time accounts, paid overtime, involuntary part-time, or fixed-term or temporary agency contracts; $0=$ none of these four). 23 percent of the full sample enterprises have neither internal nor external flexibility; 47 percent has one; and 30 percent have both. All these component and composite measures harbor substantial variation in flexible working conditions that provide leverage to judge both Hypotheses One and Two.

Independent variable: Foreign-born share of employment. Our measure of immigration is foreign-born share of employment, based on measures of total employees, foreign-born employees, and native employees in each of the sample establishments' sector of operation, all available only for one year, roughly 2003. The data come from OECD STAN Database (for employment in all sectors) and from OECD International Migration Database (for native and foreign-born employees)(all accessed in October 2010). The ESWT survey categorizes the surveyed establishments in thirteen one-digit NACE sectors. The OECD provides data on the above globalization variable, categorized by ISIC code that can be matched one-to-one with the NACE categorization after simple concordance for most though not all of the ESWT sample countries. Non-OECD European countries are excluded as a result. Foreign born share is the total foreign-born employees as a share of total sector employment.

Controls. To test the impact of immigration on flexibility we also control for factors that prior research has shown to significantly shape both. Establishment size is a categorical variable of total employees, ranging from 1 (10-19 employees) to 10 (500 or more employees). Larger establishments should have more flexibility, as they tend to have specialized 
departments and legal expertise to implement flexible work systems. Female share, the share of female employees in the workforce, is measured as a categorical variable with seven brackets ranging from 1 (none at all) to 7 (all). We expect female proportion to be positively associated with external flexibility and negatively with internal flexibility, reflecting how women disproportionately work part-time hours for reasons of work-life balance. Skilled workers, a high proportion of employees in skilled jobs requiring an apprenticeship, a university degree or other specific professional training, is a categorical variable measured like female share. Skill level ought to negatively correlate with external flexibility but positively with internal flexibility, given how modern manufacturing processes (i.e., just-intime production, quality management) depend more on skilled workers and greater managerial freedom in the use of that labor force. Employment loss (0=increase or stable; 1=decrease) should negatively affect flexibility given how downturns adversely affect overtime and the peripheral workforce as managers are forced to streamline their organization.

Worker representation is a dummy variable for incidence of formal workplace worker representation, including works councils or unions. We expect such representation to increase flexibility, given that unions and works councils tend to embrace flexibility to protect employment, wages or standard weekly hours (Burgoon and Raess 2009). Old East Europe is a dummy for East European establishments existing prior to 1989, capturing differences in productivity and correlating with higher flexibility to offset lagging productivity. Difficulty finding workers is a dummy variable based on a question about difficulty finding skilled or unskilled employees, a factor that might influence as much as reflect globalization and that should increase flexibility, especially internal flexibility for existing workers. Parents on leave, a dummy based on whether some workers have taken parental leave, captures the profile of those possibly wanting to re-enter the labor market on a part-time basis; the need for temporary employees to replace those on leave; and the direct pressure on flexibility of 
incumbent workers. Older workers is a categorical variable of the share of employees older than 50 measured on a scale from 1 (none) to 7 (all), to capture workers less capable and/or willing to work flexibly, but also in more precarious employment due to the specter of skill redundancy. We finally control for interview type, since the ESWT surveys were usually carried out with management only, but sometimes with management and employee representatives together (about one-third of the sample). Appendix One provides all summary statistics.

Estimation approach. We test our Hypotheses with probit models of per countryestablishment employment flexibility, in particular: binary components of fixed-term or agency work, involuntary part-time work, balancing-time accounts, paid overtime; and binary composite of all four features, combined flexibility. We also report ordered probit models for categorical composites of external flexibility, internal flexibility, and combined flexibility. We report estimations with the full sample and controls, though also considered a range of alternative specifications discussed below. To absorb unmeasured, country-specific differences beyond the substantive parameters and address heteroskedasticity, all estimates include country dummies. And we include sample weights, given strong reasons to suspect that substantive variables are insufficient to address sampling bias. ${ }^{7}$ All baseline models estimate Huber-White robust-cluster 'sandwich' standard errors, clustered over industries, to address unit-level heteroskedasticity and correlation (Moulton 1990).

\section{Results}

Table One summarizes the results relevant to testing Hypotheses One and Two. The first three columns show the estimates of how foreign-born share affect the incidence of external flexibility measures: fixed-term or agency work (column 1); involuntary part-time work (column 2); and the categorical composite of both, external flexibility (column 3). The 
middle three columns summarize results from the same specifications for the incidence of internal flexibility: balancing-time accounts (column 4); paid overtime (column5); and the categorical composite of both, internal flexibility (column 6). The last two columns summarize results for combined flexibility.

The controls perform in line with expectation. Larger establishments, and those having difficulty finding workers, parents on leave, older workers, and worker representation all tend to have higher external and internal flexibility. Establishments from East Europe and facing employment reductions tend to have reduced such flexibility. Establishments with higher female shares tend to have more external but less internal flexibility, while the reverse holds for higher-skilled workers share. Internal and external flexibility correlate positively with one another, suggesting that they are possible complements, not substitutes. Country dummies are highly jointly significant. The models generally perform modestly in the aggregate, however, and do so even if one throws all measures from the survey into alternative estimations.

[[Table One here]]

The main results provide mixed support for Hypothesis One and clear support for Hypothesis Two. The first three columns reveal immigration to significantly increase the measures of external flexibility. Although the positive effects of foreign-born share are statistically significant at standard levels for both fixed-term or agency workers and involuntary part-time workers, the substantive effect of the latter is twice that of the former. Furthermore, additive composite of the two components, composite external flexibility, is also highly significantly spurred by foreign-born share of employees.

Figure One clarifies the substantive meaning of these statistically significant effects. The left-hand panel calculates the increase in predicted probabilities of enterprises having fixed-term or temporary agency workers as one moves from the $1^{\text {st }}$ through the $99^{\text {th }}$ percentile of the sample distribution in foreign-born employment share - holding all other parameters at 
their medians (based on model 1). The right-hand panel, in turn, summarizes the predicted probability of having involuntary part-time workers across the same distribution of foreignborn share (based on model 2). Both panels also include the distributions for the 95-percent confidence interval and show (with the vertical line) the sample median and $90^{\text {th }}$ percentile in immigration. The predicted probabilities across the panels can be compared, though one should keep in mind that the sample distributions are different, with .7 of the sample establishments actually reporting fixed-term or agency workers and only .12 of the establishments reporting involuntary part-time. Foreign-born share, hence, more significantly increases the latter than it does the former. Moving from the $50^{\text {th }}$ to the $90^{\text {th }}$ percentile in foreign-born share predicts a 7 percentage-point rise in fixed-term or agency workers (from 54 to 60 percent chance), but a 50 percentage points rise in the chance of having involuntary part-time workers (from 6 to 56 percent).

[[Figure One here]]

Columns (4) through (6), however, make it very clear that foreign-born shares do not affect the measures of internal flexibility. For both balancing-time accounts and paid overtime the immigration measure has no discernible effects. And the result is the same with respect to the additive composite measure, composite internal flexibility (column 6). The final two columns show, however, that the effects for external flexibility tend to dominate those for internal flexibility, as both measures of the incidence of combined flexibility are significantly and substantively increased by higher foreign-born shares. Figure Two clarifies the substantive meaning of this effect, where moving from the $50^{\text {th }}$ to the $90^{\text {th }}$ percentile in foreign-born share predicts a rise of 23 percentage points in the chance that an enterprise has at least one of the four kinds of working-time flexibility (from 62 to a 85 percent chance).

[[Figure Two here]] 
These results provide a mixed picture, hence, for Hypothesis One: foreign-born share has strong spurring implications for some of, but not all, the measured manifestations of flexible working conditions. However, the patterns are clearly in line with Hypothesis Two: foreign-born share clearly has a stronger influence on the faces of flexibility connected to nonstandard working contracts than for the working-time practices of core workers.

To further explore these patterns, we considered whether internal and external flexibility are imperfect substitutes. As we already saw in the above specifications, the two kinds of flexibility are positively related to one another. But we also considered whether migration has less positive effects for external flexibility where internal flexibility is higher (or any other interaction between migration and internal or external flexibility). We find that the interactions are significantly negative only for involuntary part-time, suggesting that internal and external flexibility tend not to be imperfect substitutes (results available upon request). Such patterns go against the findings of Atkinson (1984) and are more in line with the view of Lillie (2012) that employers may use external flexibility to pressure core workers.

Our results are robust to alternative specifications. They are robust to other constellations of controls, for instance excluding skilled, old or other reported controls, and to alternate coding of controls, including the use of dummies for variables like size, female or older workers shares. We also considered but do not report other controls, either because they are more likely effects of globalization or flexibility than causes of such, or because they pose multicollinearity problems. For instance, controlling for sector wages or industry dummies, while generating multicollinearity problems, do not change the signs and significance of the main results. Controlling for standard weekly hours doesn't change the results either. Excluding any country or extreme values of the key explanatory variables do not change the reported results. Alternate estimation of standard errors (e.g., clustering over countries) yields very similar results. Alternative estimators, including multi-level random-coefficient random- 
intercept models, corroborate the reported results. Finally, the results are robust to alternative measures of the dependent variables, including binary measures of internal and external flexibility, and measures of external flexibility with incidence and proportion of part-time and of internal flexibility comprising general measures of incidence and proportion of overtime.

\section{Conclusion}

This paper explores whether workplace exposure to immigration influences the incidence of employment flexibility in European economies. Our analysis of establishmentlevel flexibility in sixteen countries suggests 'yes', but in ways that vary across aspects of flexibility. Establishments with higher foreign-born shares of workers are more likely to introduce fixed-term, temporary agency and employer-mandated part-time work contracts. But they are no more likely than establishments with few or no foreign-born employees to introduce paid overtime or balancing-time accounts for core workers. These patterns comport only in part with popular wisdom about how economic globalization as a whole unleashes pressures that alter negotiations over flexibility in workplaces toward less employee-friendly conditions. Immigration may mean more flexibility as a generalization, but that generalization masks immigration's influence on external but not internal flexibility.

Further study should consider the robustness of the results to broader samples of enterprises and countries, to over-time developments, and to more fine-grained measures of immigration and flexibility. We also need further study of the economic insecurities or other reasons why immigration might have the effects we identify, including exploration of whether the effects of immigration are functions of composition or other effects. Further research should also consider how immigration's effects for flexibility might be mediated by institutional conditions at the level of the enterprise, industry or country - building on modest research in this direction (Alsos and Eldring 2008; Burgoon and Raess 2009). 


\section{References}

Alsos, K. and Eldring, L. (2008). 'Labour mobility and wage dumping: the case of Norway'. European Journal of Industrial Relations, 14: 441-459.

Atkinson, J. (1984). 'Manpower strategies for flexible organization'. Personnel Management, 16: $28-31$.

Beard, K. M. and Edwards, J. R. (1995). 'Employees at Risk: Contingent Work and the Psychological Experience of Contingent Workers'. In C. L. Cooper and D. M. Rousseau (eds), Trends in Organizational Behavior. Chichester, UK: Wiley, pp. 109-126.

Beck, U. (2000). The Brave New World of Work. Oxford: Blackwell.

Blair-Loy, M. and Jacobs, J.A. (2003). 'Globalization, Work Hours, and the Care Deficit among Stockbrokers'. Gender \& Society, 17: 230-249.

Booth, A. L. and van Ours, J. C. (2008). 'Job Satisfaction and Family Happiness: The Parttime Work Puzzle’. The Economic Journal, 118: 77-99.

Borjas, G.J., Freeman, R.B. and Katz, L.F. (1992). 'On the Labor Market Effects of Immigration and Trade'. In G. J. Borjas and R. B. Freeman (eds), Immigration and the Workforce: Economic Consequences for the United States and Source Areas. Chicago: University of Chicago Press, pp. 213-244.

Borjas, G.J., Freeman, R.B. and Katz, L. (1996). 'Searching for the Effect of Immigration on the Labor Market'. American Economic Review, 86: 246-251.

Bosch, G. (1990). 'From 40 to 35 hours: Reduction and Flexibilisation of the Working Week in the Federal Republic of Germany'. International Labour Review, 129: 611-627.

Bosch, G. and Lehndorff, S. (2001). 'Working-time reduction and employment: Experiences in Europe and economic policy recommendations'. Cambridge Journal of Economics, 25: $209-243$. 
Burgoon, B. and Raess, D. (2009). 'Globalization and Working Time: Working Hours and Flexibility in Germany'. Politics \& Society, 37: 554-575.

Camarota, S. A. (1998). 'The Wages of Immigration: The Effect on the Low-Skilled Labor Market'. Center Paper 12, Washington, D.C., Center for Immigration Studies.

Cappelli, P. (1999). The New Deal at Work: Managing the Market-Driven Workforce.

Cambridge: Harvard Business School Press.

Cappelli, P. and Neumark, D. (2004). 'External Churning and Internal Flexibility: Evidence on the Functional Flexibility and Core-Periphery Hypotheses'. Industrial Relations, 43: 148-182.

De Graaf-Zijl, M. (2005). 'The economic and social consequences of temporary employment: a review of the literature'. SEO discussion paper 47.

De Witte, H. and Näswall, K. (2003). “"Objective” vs. "Subjective” Job Insecurity: Consequences of Temporary Work for Job Satisfaction and Organizational Commitment in Four European Countries'. Economic and Industrial Democracy, 24: $139-148$.

De Wolff, A. (2000). Breaking the Myth of Flexible Work: Contingent Work in Toronto. Toronto: Toronto Organizing for Fair Employment.

Doogan, K. (2005). 'Long-term Employment and the Restructuring of the Labour Market in Europe'. Time \& Society 14: 65-87.

DuMouchel, W.H. and Duncan, G. (1983). 'Using Sample Survey Weights in Multiple Regression Analyses of Stratified Samples'. Journal of the American Statistical Association, 78: 535-542.

Erlinghagen, M. (2008). 'Self-Perceived Job Insecurity and Social Context: A Multi-Level Analysis of 17 European Countries'. European Sociological Review, 24: 183-197. 
European Commission (2006). Industrial Relations in Europe. Brussels: European

Commission.

European Foundation for the Improvement of Living and Working Conditions and TNS Infratest Sozialforschung (Munich)(2007). Establishment Survey on Working Time and Work-Life Balance, 2004-2005 [computer file]. Colchester, Essex: UK Data Archive [distributor], July. SN: 5655.

Feenstra, R.C. and Hanson, G.H. (1996). 'Globalisation, outsourcing and wage inequality' American Economic Review, 86: 240-245.

Flanagan, R.J. (2006). Globalization and labor conditions: Working conditions and worker rights in a global economy. New York, Oxford University Press.

Gash, V., and McGinnity, F. (2007). 'Fixed-term contracts - the new European inequality? Comparing men and women in West Germany and France.' Socio-Economic Review, 5: 467-496.

Golden, L.and Appelbaum, E. (2006). 'What was Driving the 1982-88 Boom in Temporary Employment?: Preference of Workers or Decisions and Power of Employers?' American Journal of Economics and Sociology, 51: 473-493.

Green, C., Kler, P. and Leeves, G. (2010). 'Flexible Contract Workers in Inferior Jobs: Reappraising the Evidence'. British Journal of Industrial Relations, 48: 605-629.

Guest, D. (2004). 'Flexible Employment Contracts, the Psychological Contract and Employee Outcomes: An Analysis and Review of the Evidence.' International Journal of Management Reviews, 5-6: 1-19.

Gustafsson, S., Kenjoh, E. and Wetzels, C. (2003). 'Employment Choices and Pay Differences between Nonstandard and Standard Work in Britain, Germany, the Netherlands, and Sweden'. In S. Houseman and M. Osawa (eds), Nonstandard Work in Developed Economies. Minneapolis, MN: W.E. Upjohn Institute. 
Hanson, G.H., Mataloni, R. and Slaughter, M. (2001). 'Expansion Strategies of U.S. Multinational Firms'. In D. Rodrik and S. Collins (eds), Brookings Trade Forum 2001. Washington D.C.: The Brookings Institution, pp. 245-294.

Haworth, N. and Hughes, S. (2003). 'International Political Economy and Industrial Relations'. British Journal of Industrial Relations, 41: 665-682.

Heery, E. and Salmon, J. (eds) (2000). The insecure workforce. London: Routledge. Hinrichs, K., Roche, W. and Sirianni, C. (eds) (1991). Working Time in Transition: The Political Economy of Working Hours in Industrial Nations. Philadelphia, PA, Temple University Press.

Hunter, L., McGregor, A., Maclnnes, J. and Sproull, A. (1993). ‘The “Flexible Firm”: Strategy and Segmentation'. British Journal of Industrial Relations, 31: 383-407. Jirjahn, U. (2008). 'On the Determinants of Shift Work and Overtime Work: Evidence from German Establishment Data'. British Journal of Industrial Relations, 46: 133-168.

Kalleberg, A. L. (2001). 'Organizing Flexibility: The Flexible Firm in a New Century'. British Journal of Industrial Relations, 39: 479-504.

Kalleberg, A. L. (2000). 'Nonstandard Employment Relations: Part-time, Temporary and Contract Work'. Annual Review of Sociology, 26: 341-365.

Katzenstein, P. J. (1985). Small States in World Markets: Industrial Policy in Europe. Ithaca: Cornell University Press.

King, D and Rueda, D. (2008). 'Cheap Labor: The New Politics of "Bread and Roses" in Industrial Democracies'. Perspectives on Politics, 6: 279-297.

Knell, J. (2000). Most Wanted: The Quiet Birth of the Free Worker. London: Industrial Society.

Krausz, M. (2000). 'Effects of short- and long-term preference for temporary work upon psychological outcomes'. International Journal of Manpower 21: 635-647. 
Lillie, N. (2012). 'Subcontracting, Posted Migrants and Labour Market Segmentation in Finland'. British Journal of Industrial Relations 50: 148-167.

Lillie, N. and Greer, I. (2007). 'Industrial Relations, Migration, and Neoliberal Politics: The Case of the European Construction Sector'. Politics \& Society, 35: 551-581.

MacKenzie, R. and Forde C. (2009) 'The rhetoric of the "good worker" versus the realities of employers' use and the experiences of migrant workers'. Work, employment and society, 23: $142-159$

McDowell, L., Batnitzky, A. and Dyer, S. (2008). 'Internationalization and the Spaces of Temporary Labour: The Global Assembly of a Local Workforce'. British Journal of Industrial Relations, 46: 750-770.

McDuffie, J. P. (1995). ‘Human resource bundles and manufacturing performance; organizational logic and flexible production systems in the world auto industry.' Industrial and Labor Relations Review, 48: 197-221.

McGovern, P. (2007). 'Immigration, Labour Markets and Employment Relations: Problems and Prospects', British Journal of Industrial Relations, 45: 217-235.

Moulton, B. (1990). 'An Illustration of a Pitfall in Estimating the Effects of Aggregate Variables on Micro Units'. Review of Economics and Statistics, 72: 334-338.

Newman, K. and Lennon, C. (1995). 'Finding Work in the Inner City: How Hard Is It Now? How Hard Will It Be for Welfare Recipients?' Working Paper 67, New York, NY, Russell Sage Foundation.

OECD (2008). A Profile of Immigrant Populations in the $21^{\text {st }}$ Century: Data from OECD Countries. Paris: OECD.

Okkerse, L. (2008). 'How to measure labour market effects of immigration: a review'. Journal of Economic Survey, 22: 1-30. 
Olsen, K.M. (2005). ‘Unions’ Dilemma When Firms Use Employment Intermediaries’.

European Sociological Review, 21: 289-300.

Piore, M. (1979). Birds of Passage. New York: Cambridge University Press.

Plantenga, J. and Dur, R. (1998). 'Working time reduction in the Netherlands: past developments and future prospects'. Transfer: European Review of Labour and Research, 4: 678-691.

Raess, D. and Burgoon, B. (2006). 'The Dogs that Sometimes Bark: Globalization and Works Council Bargaining in Germany'. European Journal of Industrial Relations, 12: 287309.

Smith, V. and Neuwirth, E.B. (2008). The Good Temp. Ithaca, NY: Cornell University Press.

Tijdens, K. (2003). 'Employees’ and Employers’ Preferences for Working Time Reduction and Working Time Differentiation: A Study of the 36-Hour Working Week in the Dutch Banking Sector'. Acta Sociologica, 46: 69-82.

Väisänen, M. and Nätti, J. (2002). 'Working time preferences in dual-earning households'. European Societies, 4: 307-329.

Waldinger, R.D. and Lichter M.I. (2003). How the other half works: immigration and the social organization of labor. Berkley: University of California Press.

Winship, C. and Radbill, L. (1994). 'Sampling Weights and Regression Analysis'. Sociological Methods and Research, 23: 230-257.

Woolfson, C. (2007). 'Labour standards and migration in the new Europe: post-communist legacies and perspectives'. European Journal of Industrial Relations, 13: 199-218. 
Table One:

Probit Estimates of External and Internal Flexibility

\begin{tabular}{|c|c|c|c|c|c|c|c|c|}
\hline & \multicolumn{3}{|c|}{ External flexibility } & \multicolumn{3}{|c|}{ Internal Flexibility } & \multicolumn{2}{|c|}{ Combined Flexibility } \\
\hline & $\begin{array}{l}\text { Fixed-term } \\
\text { or } \\
\text { temporary } \\
\text { work } \\
\text { (1) }\end{array}$ & $\begin{array}{l}\text { Involuntary } \\
\text { part-time } \\
\text { work } \\
\text { (2) }\end{array}$ & $\begin{array}{l}\text { Composite } \\
\text { external } \\
\text { flexibility } \\
(3)\end{array}$ & $\begin{array}{l}\text { Balancing } \\
\text {-time } \\
\text { accounts } \\
(4)\end{array}$ & $\begin{array}{l}\text { Paid } \\
\text { overtime } \\
\text { (5) }\end{array}$ & $\begin{array}{l}\text { Composite } \\
\text { internal } \\
\text { flexibility } \\
(6)\end{array}$ & $\begin{array}{l}\text { Combined } \\
\text { flexibility } \\
\text { categorical } \\
\text { (7) }\end{array}$ & $\begin{array}{l}\text { Combined } \\
\text { flexibility } \\
\text { binary } \\
\text { (8) }\end{array}$ \\
\hline Foreign born & $\begin{array}{c}1.860 * * * \\
(0.715)\end{array}$ & $\begin{array}{c}4.174 * * \\
(1.655)\end{array}$ & $\begin{array}{c}3.396 * * * \\
(0.901)\end{array}$ & $\begin{array}{c}0.223 \\
(1.021)\end{array}$ & $\begin{array}{l}-1.551 \\
(0.994)\end{array}$ & $\begin{array}{c}-0.764 \\
(0.918)\end{array}$ & $\begin{array}{c}1.629 * * * \\
(0.542)\end{array}$ & $\begin{array}{c}1.863 * * * \\
(0.575)\end{array}$ \\
\hline Size & $\begin{array}{c}0.183 * * * \\
(0.020)\end{array}$ & $\begin{array}{c}0.062 * * * \\
(0.012)\end{array}$ & $\begin{array}{c}0.127 * * * \\
(0.010)\end{array}$ & $\begin{array}{l}-0.021 \\
(0.016)\end{array}$ & $\begin{array}{c}0.035^{* *} \\
(0.015)\end{array}$ & $\begin{array}{c}0.010 \\
(0.009)\end{array}$ & $\begin{array}{c}0.088^{* * *} \\
(0.008)\end{array}$ & $\begin{array}{c}0.129 * * * \\
(0.022)\end{array}$ \\
\hline Female share & $\begin{array}{c}0.045 * * * \\
(0.013)\end{array}$ & $\begin{array}{c}0.154 * * * \\
(0.026)\end{array}$ & $\begin{array}{c}0.093 * * * \\
(0.016)\end{array}$ & $\begin{array}{c}0.017 \\
(0.015)\end{array}$ & $\begin{array}{c}-0.135 * * * \\
(0.020)\end{array}$ & $\begin{array}{c}-0.077 * * * \\
(0.014)\end{array}$ & $\begin{array}{c}0.006 \\
(0.015)\end{array}$ & $\begin{array}{l}-0.011 \\
(0.025)\end{array}$ \\
\hline Skilled workers & $\begin{array}{l}-0.059 \\
(0.061)\end{array}$ & $\begin{array}{c}-0.174 * * * \\
(0.058)\end{array}$ & $\begin{array}{c}-0.109 * * * \\
(0.039)\end{array}$ & $\begin{array}{c}0.132 * * \\
(0.066)\end{array}$ & $\begin{array}{l}-0.060 \\
(0.083)\end{array}$ & $\begin{array}{c}0.050 \\
(0.050)\end{array}$ & $\begin{array}{l}-0.037 \\
(0.045)\end{array}$ & $\begin{array}{l}-0.069 \\
(0.060)\end{array}$ \\
\hline Employment loss & $\begin{array}{c}-0.093 * * * \\
(0.028)\end{array}$ & $\begin{array}{c}0.001 \\
(0.039)\end{array}$ & $\begin{array}{c}-0.065^{* *} \\
(0.028)\end{array}$ & $\begin{array}{c}-0.046 * * * \\
(0.016)\end{array}$ & $\begin{array}{c}-0.069 * * * \\
(0.015)\end{array}$ & $\begin{array}{c}-0.072 * * * \\
(0.013)\end{array}$ & $\begin{array}{c}-0.091 * * * \\
(0.024)\end{array}$ & $\begin{array}{c}-0.080^{*} \\
(0.046)\end{array}$ \\
\hline Worker representation & $\begin{array}{c}0.159 * * * \\
(0.054)\end{array}$ & $\begin{array}{c}0.006 \\
(0.141)\end{array}$ & $\begin{array}{c}0.126 \\
(0.079)\end{array}$ & $\begin{array}{c}0.044 \\
(0.054)\end{array}$ & $\begin{array}{c}0.041 \\
(0.074)\end{array}$ & $\begin{array}{c}0.053 \\
(0.040)\end{array}$ & $\begin{array}{c}0.119 * * \\
(0.059)\end{array}$ & $\begin{array}{c}0.205 * * * \\
(0.074)\end{array}$ \\
\hline Old E.Europe & $\begin{array}{c}-0.378 * * * \\
(0.102)\end{array}$ & $\begin{array}{l}-0.113 \\
(0.122)\end{array}$ & $\begin{array}{c}-0.335 * * * \\
(0.123)\end{array}$ & $\begin{array}{c}0.095 \\
(0.136)\end{array}$ & $\begin{array}{l}-0.016 \\
(0.103)\end{array}$ & $\begin{array}{c}0.067 \\
(0.140)\end{array}$ & $\begin{array}{c}-0.174 * \\
(0.091)\end{array}$ & $\begin{array}{l}-0.238^{*} \\
(0.133)\end{array}$ \\
\hline Difficulty finding workers & $\begin{array}{c}0.159 * * * \\
(0.048)\end{array}$ & $\begin{array}{c}0.054 \\
(0.051)\end{array}$ & $\begin{array}{c}0.129 * * * \\
(0.048)\end{array}$ & $\begin{array}{l}-0.001 \\
(0.035)\end{array}$ & $\begin{array}{c}0.227 * * * \\
(0.063)\end{array}$ & $\begin{array}{c}0.140 * * * \\
(0.035)\end{array}$ & $\begin{array}{c}0.177 * * * \\
(0.042)\end{array}$ & $\begin{array}{c}0.181 * * * \\
(0.038)\end{array}$ \\
\hline Parents on leave & $\begin{array}{c}0.137 * * * \\
(0.037)\end{array}$ & $\begin{array}{c}0.007 \\
(0.085)\end{array}$ & $\begin{array}{c}0.105 * * \\
(0.050)\end{array}$ & $\begin{array}{c}0.123 * * * \\
(0.040)\end{array}$ & $\begin{array}{c}0.045 \\
(0.044)\end{array}$ & $\begin{array}{c}0.109 * * * \\
(0.028)\end{array}$ & $\begin{array}{c}0.142 * * * \\
(0.045)\end{array}$ & $\begin{array}{c}0.229 * * * \\
(0.071)\end{array}$ \\
\hline Older workers & $\begin{array}{l}-0.013 \\
(0.020)\end{array}$ & $\begin{array}{c}0.045 \\
(0.037)\end{array}$ & $\begin{array}{c}0.011 \\
(0.021)\end{array}$ & $\begin{array}{c}0.034 * * * \\
(0.013)\end{array}$ & $\begin{array}{c}0.010 \\
(0.015)\end{array}$ & $\begin{array}{c}0.030^{* * * *} \\
(0.010)\end{array}$ & $\begin{array}{c}0.027 * * \\
(0.012)\end{array}$ & $\begin{array}{c}0.028 * * \\
(0.014)\end{array}$ \\
\hline Internal flexibility & $\begin{array}{c}0.065 \\
(0.043)\end{array}$ & $\begin{array}{c}0.050 \\
(0.032)\end{array}$ & $\begin{array}{c}0.062 * * \\
(0.030)\end{array}$ & & & & & \\
\hline External flexibility & & & & $\begin{array}{c}0.093 * * * \\
(0.019)\end{array}$ & $\begin{array}{c}0.009 \\
(0.053)\end{array}$ & $\begin{array}{c}0.063 * * \\
(0.032)\end{array}$ & & \\
\hline Log pseudo-likelihood & -5541.85 & -3189.86 & -7866.03 & -5158.48 & -5452.89 & -8178.0 & -11540.91 & -3757.32 \\
\hline Total observations & 9502 & 9502 & 9502 & 9502 & 9502 & 9502 & 9502 & 9502 \\
\hline Pseudo-R2 & 0.12 & 0.13 & 0.08 & 0.07 & 0.11 & 0.04 & 0.04 & 0.08 \\
\hline
\end{tabular}

Columns (1), (2), (4), (5), (8): Probit coefficients. 
Columns (3), (6), (7): Ordered probit coefficients.

All models: Robust standard errors (in parentheses), clustered over industry. Cuts, country dummies and interview-type dummy not shown.

$* * * \mathrm{p}<0.01, * * \mathrm{p}<0.05, * \mathrm{p}<0.1$ 
Figure One:

Immigration and External Flexibility
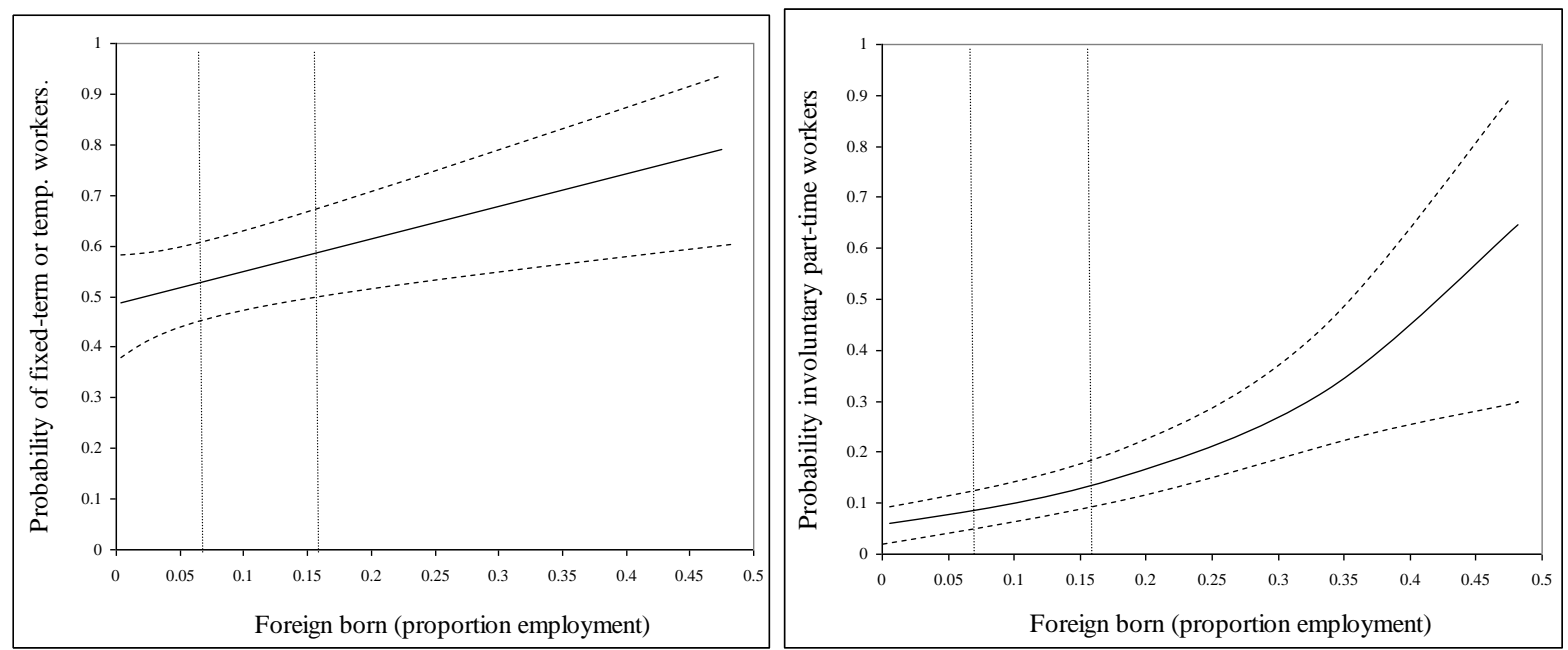

Figure Two:

Immigration and Total Flexibility

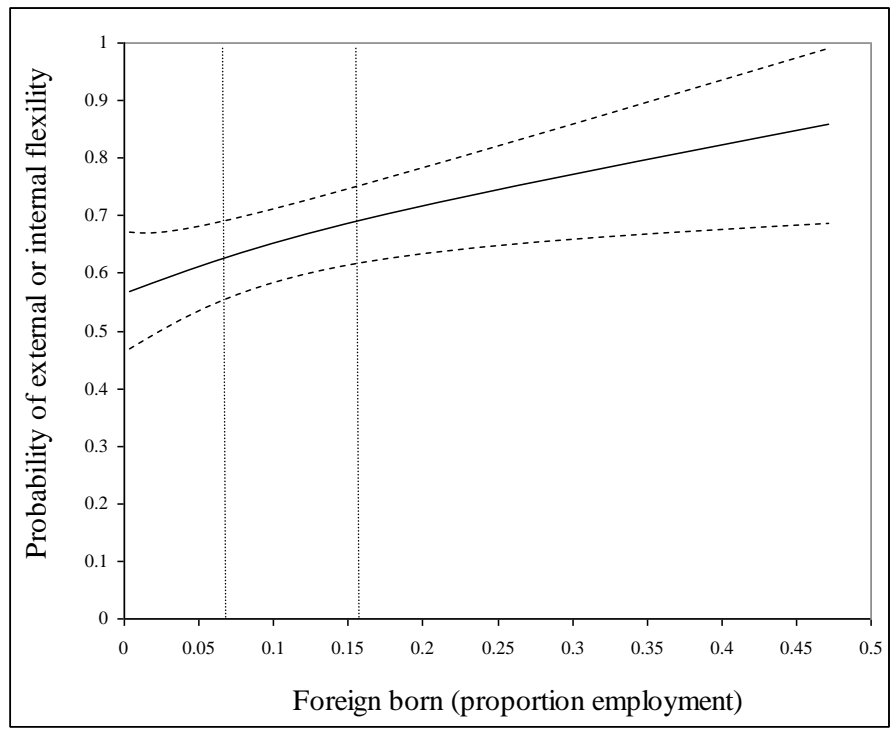


Appendix One:

Summary statistics

Variable

Fixed-term or agency work

Involuntary part-time work

Composite external flexibility

Balancing-time accounts

Paid overtime

Composite internal flexibility

Combined flexibility categorical

Combined flexibility binary

Foreign born (13 industries $x 16$ countries)

Size

Female share

Skilled workers

Employment loss

Worker representation

Old East Europe

Difficulty finding workers

Parents on leave

Older workers

Interview type

\begin{tabular}{rrr}
\multicolumn{1}{l}{ Obs } & \multicolumn{1}{l}{ Mean } & \multicolumn{1}{l}{ Dev. } \\
9502 & 0.7005 & 0.4580 \\
9502 & 0.1156 & 0.3198 \\
9502 & 0.8161 & 0.5709 \\
9502 & 0.3054 & 0.4606 \\
9502 & 0.3137 & 0.4640 \\
9502 & 0.6192 & 0.6044 \\
9502 & 1.4353 & 0.8453 \\
9502 & 0.8734 & 0.3326 \\
208 & 0.0868 & 0.0807 \\
9502 & 3.2404 & 2.6230 \\
9502 & 3.2294 & 1.3945 \\
9502 & 0.3556 & 0.4787 \\
9502 & 1.8545 & 0.7792 \\
9502 & 0.4250 & 0.4944 \\
9502 & 0.0564 & 0.2308 \\
9502 & 0.4147 & 0.4927 \\
9502 & 0.6052 & 0.4888 \\
9502 & 2.4050 & 0.9256 \\
9502 & 0.2010 & 0.4008
\end{tabular}

$\begin{array}{rr}\text { Min } & \text { Max } \\ 0 & 1 \\ 0 & 1 \\ 0 & 2 \\ 0 & 1 \\ 0 & 1 \\ 0 & 2 \\ 0 & 4 \\ 0 & 1 \\ 0.0047 & 0.7442 \\ 1 & 10 \\ 1 & 7 \\ 0 & 1 \\ 1 & 3 \\ 0 & 1 \\ 0 & 1 \\ 0 & 1 \\ 0 & 1 \\ 1 & 7 \\ 0 & 1\end{array}$

\footnotetext{
${ }^{1}$ King and Rueda (2008) focus on fixed-term and part-time work contracts as strongly correlated among advanced industrial countries, where high temporary employment obviates the need for part-time employment. ${ }^{2}$ Unfortunately, our data do not allow us to test, here, whether this or the composition effect is more important. ${ }^{3}$ The reported results exclude public enterprises, because public establishments are subject to different exogenous conditions influencing contracting and working time arrangements than applies to private establishments. Still, all the reported results have been replicated with public enterprises as well.

${ }^{4}$ This measure combines one question on incidence of 'fixed-term or temporary workers', and one on incidence of 'temporary agency workers'. We combine these to avoid double counting: affirmative answers to the former may concern temporary workers from temporary agencies that are counted again with the latter measure. Unfortunately, the ESWT survey includes no question on the proportion of fixed-term and temporary workers. ${ }^{5}$ The questionnaire asks whether part-time was introduced mainly to meet (1) the needs of the establishment (2) the wishes of the employees or (3) both. Survey responses (1) build our measure of employer-mandated parttime, which is reasonable proxy for involuntary part-time because it excludes the possibility that such employment conforms to employee preference (i.e., survey responses (2) or (3)). In other words, it is likely that most employer-mandated part-time posts will be filled by plenty of workers not preferring to work part-time. ${ }^{6}$ All four components for external and internal flexibility capture variation that, upon being aggregated to the national averages, strongly positively correlate with other national measures of fixed-term, part-time, balancingtime, and overtime work in other data.

${ }^{7}$ For instance, the establishment-weight parameter significantly interacts with the immigration measure. And the substantive parameters in the dataset cannot capture all reasons why some enterprises are under or over sampled in the ESWT survey (see DuMouchel and Duncan 1983; Winship and Radbill 1994).
} 